\title{
Susceptibility of Escherichia coli isolated from uteri of postpartum dairy cows to antibiotic and environmental bacteriophages. Part I: Isolation and lytic activity estimation of bacteriophages
}

\author{
R. C. Bicalho, ${ }^{* 1}$ T. M. A. Santos, ${ }^{*}$ R. O. Gilbert, $†$ L. S. Caixeta, ${ }^{*}$ L. M. Teixeira, $\ddagger$ M. L. S. Bicalho, ${ }^{*}$ \\ and V. S. Machado* \\ *Department of Population Medicine and Diagnostic Sciences, College of Veterinary Medicine, \\ †Department of Clinical Sciences, College of Veterinary Medicine, and \\ ‡Department of Microbiology, College of Agriculture and Life Sciences, Cornell University, Ithaca, NY 14853
}

\begin{abstract}
The objective of this study was to isolate bacteriophages from environmental samples of 2 large commercial dairy farms using Escherichia coli isolated from the uteri of postpartum Holstein dairy cows as hosts. A total of 11 bacteriophage preparations were isolated from manure systems of commercial dairy farms and characterized for in vitro antimicrobial activity. In addition, a total of $57 \mathrm{E}$. coli uterine isolates from 5 dairy cows were phylogenetically grouped by triplex PCR. Each $E$. coli bacterial host from the uterus was inoculated with their respective bacteriophage preparation at several different multiplicities of infections (MOI) to determine minimum inhibitory MOI. The effect of a single dose $\left(\mathrm{MOI}=10^{2}\right)$ of bacteriophage on the growth curve of all $57 \mathrm{E}$. coli isolates was assessed using a microplate technique. Furthermore, genetic diversity within and between the different bacteriophage preparations was assessed by bacteriophage purification followed by DNA extraction, restriction, and agarose gel electrophoresis. Phylogenetic grouping based on triplex PCR showed that all isolates of E. coli belonged to phylogroup B1. Bacterial growth was completely inhibited at considerably low MOI, and the effect of a single dose (MOI $=10^{2}$ ) of bacteriophage preparations on the growth curve of all $57 \mathrm{E}$. coli isolates showed that all bacteriophage preparations significantly decreased the growth rate of the isolates. Bacteriophage preparation 1230-10 had the greatest antimicrobial activity and completely inhibited the growth of $71.7 \%(\mathrm{n}=57)$ of the isolates. The combined action of bacteriophage preparations 1230-10, 6375-10, 2540-4, and 6547-2, each at MOI $=10^{2}$, had the broadest spectrum of action and completely inhibited the growth (final optical density at 600 $\mathrm{nm} \leq 0.1$ ) of $80 \%$ of the $E$. coli isolates and considerably inhibited the growth (final optical density at $600 \mathrm{~nm}$
\end{abstract}

Received April 15, 2009.

Accepted October 1, 2009.

${ }^{1}$ Corresponding author: rcb28@cornell.edu $\leq 0.2$ ) of $90 \%$ of the E. coli isolates. Restriction profile analysis demonstrated that all 4 phage preparations contained bacteriophages that were genetically distinct from each other according to the banding pattern of the fragments. The combination of several different bacteriophages can improve the spectrum of action, and the results of this study suggest that bacteriophages 1230-10, 6375-10, 2540-4, and 6547-2 should be used in combination as a cocktail.

Key words: antibiotic resistance, bacteriophage therapy, dairy cow, metritis

\section{INTRODUCTION}

Postpartum uterine diseases (specifically puerperal metritis, clinical endometritis, and subclinical endometritis) are an important consideration for welfare reasons because they contribute to cow discomfort and elimination from the herd and for economic reasons because they profoundly affect reproductive performance. Puerperal metritis is defined as an animal with an abnormally enlarged uterus and a fetid, watery, red-brown uterine discharge associated with signs of systemic illness (decreased milk yield, dullness, or other signs of toxemia) and temperature $>39.5^{\circ} \mathrm{C}$ within $21 \mathrm{~d}$ after parturition (Sheldon et al., 2006). Endometritis is the inflammation of the uterus without systemic illness (Sheldon et al., 2006).

The uterus is routinely contaminated with bacteria in the early postpartum period; 80 to $100 \%$ of cows have bacterial contamination of the uterus in the first 2 wk postpartum (Foldi et al., 2006). Escherichia coli and Arcanobacterium pyogenes are considered to be the most important bacteria associated with uterine infection (Sheldon et al., 2004). However, Pseudomonas spp., Streptococcus spp., Staphylococcus spp., Pasteurella multocida, Clostridium spp., Fusobacterium spp., and Bacteroides spp. were also associated with uterine infection (Dohmen et al., 2000). Recent research indicates that the infected uterus in the first week postpar- 
tum is predominantly infected by $E$. coli, which affects the phenotype and function of polymorphonuclear cells, and this might support the coinfection by $A$. pyogenes starting in the second week postpartum (Dohmen et al., 2000; Zerbe et al., 2001). Systemic or intrauterine antibiotic therapy is commonly used as the treatment option for metritis (Sheldon et al., 2004).

Bacteriophages are viruses that infect bacteria; they are obligate intracellular parasites and lack their own metabolism. Phages are host specific, able to only infect specific species or even strains of bacteria (Barrow and Soothill, 1997). The concept of combating bacterial pathogens by means of bacteriophages is obvious and was proposed shortly after the discovery of bacteriophages approximately 90 years ago (d'Herelle, 1925). Unfortunately, the discovery of antibiotics basically eliminated research on phage therapy. However, the increasing problem of antibiotic resistance has revamped the interest in phage therapy (Summers, 2001).

Although phage therapy can be a useful tool in the battle against bacterial infections, researchers have to overcome several challenges to improve the efficacy of bacteriophage therapy, such as the rapid clearance from the blood stream and subsequent accumulation of bacteriophages in the spleen (Biswas et al., 2002), the narrow host range of most bacteriophages (Merril et al., 2003), and the large load of endo- and exotoxins present in the filter-sterilized bacteriophage lysates (Barrow et al., 1998). Recent results from randomized clinical trials in mice and cattle have shown optimistic results. Biswas et al. (2002) successfully rescued mice that were inoculated with lethal doses of vancomycinresistant Enterococcus faecium with a single injection of a phage solution containing $3 \times 10^{8}$ pfu of a certain bacteriophage. Bacteriophage therapy was also reported successful when newly borne colostrum-deprived calves were inoculated with $E$. coli and treated with intramuscular inoculation of bacteriophages (Barrow et al., 1998).

Our objective was to isolate bacteriophages from environmental samples from 2 large commercial dairy farms using wild strains of $E$. coli that were isolated from the uteri of postpartum dairy cows as hosts. Furthermore, it was our objective to assess the minimum inhibitory multiplicity of infection (MOI) of bacteriophage particles and to select a combination of bacteriophages that will have a wide spectrum of action against E. coli.

\section{MATERIALS AND METHODS}

\section{Farm, Management, and Sample Collection}

Uterine lavage was performed on 5 postpartum dairy cows that were housed in a commercial dairy farm lo- cated near Ithaca, NY. Samples were collected from October 1 until October 15, 2008. This farm was selected because of its long working relationship history with the Ambulatory and Production Medicine Clinic at Cornell University. The farm milked 2,800 Holstein cows 3 times daily in a double 52-stall parallel milking parlor. The cows were housed in freestall barns with concrete stalls covered with mattresses and bedded with waste paper pulp. All cows were offered a TMR consisting of approximately $55 \%$ forage (corn silage, haylage, and wheat straw) and $45 \%$ concentrate (corn meal, soybean meal, canola, cottonseed, and citrus pulp) on a DM basis of the diet. The diet was formulated to meet or exceed the NRC nutrients requirements for lactating Holstein cows weighing $650 \mathrm{~kg}$ and producing $45 \mathrm{~kg}$ of $3.5 \%$ FCM.

Uterine lavage was performed on a convenience sample of 5 postpartum dairy cows; the average DIM at sampling was $5 \pm 2$. To isolate $E$. coli from uterus, a uterine secretion sample was collected as follows: cows were restrained, the perineum area was cleansed and disinfected with a $70 \%$ ethyl alcohol solution, and a plastic infusion pipette (inside a plastic sheath) was introduced into the cranial vagina. There the sheath was ruptured, and the clean pipette tip was manipulated through the cervix into the uterus. A total of $40 \mathrm{~mL}$ of sterile saline solution was infused into the uterus and agitated gently, and a sample of the fluid was aspirated. The volume of recovered fluid ranged from 5 to $15 \mathrm{~mL}$. Samples were kept in ice until they were processed in the laboratory.

\section{Bacterial Isolation}

Uterine secretion was taken to the laboratory and diluted in $0.9 \%$ sodium chloride saline. The sample was cultured aerobically on MacConkey agar (Difco, Becton Dickinson, NJ) at $37^{\circ} \mathrm{C}$, and E. coli colonies were distinguished by a purple-red color. Typical $E$. coli colonies from the MacConkey agar cultures were picked and subsequently streaked on Chromagar-E. coli (DRG International, Mountainside, NJ) for confirmation and further isolation. Colonial morphology and characteristic appearance in smears stained by Gram's method were used to exam purity.

In addition, a 340-bp fragment of the bacterial 16S rRNA-encoding gene was amplified by using the primers 16SF $\left(5^{\prime}\right.$ - GTT AAT ACC TTT GCT CAT TGA $\left.-3^{\prime}\right)$ and $16 \mathrm{SR}\left(5^{\prime}-\mathrm{ACC}\right.$ AGG GTA TCT AAT CCT GTT - 3') (Malinen et al., 2003). A QIAamp DNA minikit (Qiagen Inc., Valencia, CA) was used to extract DNA according to the manufacturer's instruction. Amplification reactions were carried out in a 25$\mu \mathrm{L}$ reaction mixture containing $10 \mathrm{pmol}$ of each primer 
(Malinen et al., 2003), $0.25 \mathrm{mM}$ of each deoxynucleotide triphosphate (New England Biolabs, Beverly, MA), 2.0 $\mathrm{mM}$ of $\mathrm{MgCl}_{2}, 1 \times T a q$ polymerase buffer (New England Biolabs), 1.5 U of Taq polymerase (New England Biolabs), and $20 \mathrm{ng}$ of bacterial DNA as template. Cycling parameters were $94^{\circ} \mathrm{C}$ for 10 min followed by 30 cycles at $94^{\circ} \mathrm{C}$ for $1 \mathrm{~min}, 55^{\circ} \mathrm{C}$ for $1 \mathrm{~min}$, and $72^{\circ} \mathrm{C}$ for $1 \mathrm{~min}$. A final extension was carried out at $72^{\circ} \mathrm{C}$ for $10 \mathrm{~min}$. Polymerase chain reactions were performed in a 2720 Thermal Cycler (Applied Biosystems, Foster City, CA). Negative controls consisting of the PCR mixture without addition of DNA were included in all PCR runs. E. coli American Type Culture Collection 25404 and 25922 were used as positive controls.

The genetic diversity of $E$. coli isolates was evaluated by randomly amplified polymorphic DNA-PCR with informative primer 1283 (5' - GCG ATC CCC A - 3'), as described previously (Wang et al., 1993).

Phylogenetic grouping was performed by triplex PCR, which uses a combination of 2 genes (chuA, a gene required for heme transport in enterohemorrhagic O157:H7 E. coli, and yjaA, a gene with unknown function recently identified in E. coli) and an anonymous DNA fragment (Clermont et al., 2000). Amplification products were separated by electrophoresis through a $1.2 \%(\mathrm{wt} / \mathrm{vol})$ agarose gel, stained with $0.5 \mu \mathrm{g} / \mathrm{mL}$ ethidium bromide, and visualized with the Kodak Gel Logic 100 Imaging System (GL 100, Eastman Kodak Co., New Haven, CT). Positive results were considered to be amplicons that had the expected molecular size.

All isolates were stocked at $-80^{\circ} \mathrm{C}$ in Luria-Bertani (LB) broth (Difco) containing $20 \%$ glycerol until further testing.

\section{E. coli Bacteriophage Isolation, Preparation, and Titration}

To isolate bacteriophages, a sewage sample of $500 \mathrm{~mL}$ from the manure lagoons of 2 large commercial dairy farms was taken. In the laboratory, the samples were homogenized, and a subsample of $50 \mathrm{~mL}$ was taken and centrifuged for $25 \mathrm{~min}$ at $3,000 \times g$ at $4^{\circ} \mathrm{C}$. The supernatant was collected and filter sterilized using a $0.22-\mu \mathrm{m}$ pore size filter.

Ten $E$. coli isolates were randomly selected from the total pool of $57 \mathrm{E}$. coli isolates to serve as target hosts for the bacteriophages. In addition, one reference strain from the American Type Culture Collection numbered 25404 was used as a host. Each of the 11 E. coli hosts was separately cultured in LB broth until an optical density at $600 \mathrm{~nm}\left(\mathbf{O D}_{600}\right)$ of $0.3\left(\sim 1 \times 10^{8} \mathrm{cfu} / \mathrm{mL}\right)$ was reached. At this point, $8.8 \mathrm{~mL}$ of the sterile, filtrated sewage was inoculated with $1 \mathrm{~mL}$ of $10 \times \mathrm{LB}$ broth and $200 \mu \mathrm{L}\left(\sim 1 \times 10^{8} \mathrm{cfu} / \mathrm{mL}\right)$ of each one of the
$11 \mathrm{E}$. coli hosts. The mixtures were then incubated at $37^{\circ} \mathrm{C}$ for $18 \mathrm{~h}$ with shaking to allow the amplification of the bacteriophages. After incubation, the mixture was centrifuged at $10,000 \times g$ at $4^{\circ} \mathrm{C}$ for $10 \mathrm{~min}$, and the supernatant was sterilized by filtering through a $0.22-\mu \mathrm{m}$ pore size filter.

To test bacteriophage activity in the filtered supernatant, a spot assay that entailed placing $5 \mu \mathrm{L}$ of the supernatant on LB agar previously seeded with $E$. coli was performed for each one of the $11 \mathrm{E}$. coli hosts. The inoculated plates were incubated for $18 \mathrm{~h}$ at $37^{\circ} \mathrm{C}$ and then checked for the presence of a lytic zone.

After confirmation of phage activity, a high-titer stock in SM buffer $\left(100 \mathrm{~m} M \mathrm{NaCl}, 8 \mathrm{mM} \mathrm{MgSO}_{4}, 1 M\right.$ TrisHCI, pH 7.5) was prepared according to Sambrook and Russell (2001) for each bacteriophage solution. These high-titer stocks were used to determine the minimum inhibitory MOI (miMOI) of bacteriophage particles. Furthermore, the high-titer stocks of bacteriophages were titrated using the standard soft agar overlay technique (Clokie and Kropinski, 2009).

\section{Determination of the miMOI}

To assess the effect of inoculation of several ratios of bacteriophages and bacteria on the growth curve of each host $E$. coli isolate and determine the miMOI, the following procedure was performed. E. coli isolates were grown in LB broth at $37^{\circ} \mathrm{C}$ for 6 to $8 \mathrm{~h}$ with shaking until an $\mathrm{OD}_{600}$ of $0.3\left(\sim 1 \times 10^{8} \mathrm{cfu} / \mathrm{mL}\right)$ was reached. The cultures were then diluted in LB broth to $10^{5} \mathrm{cfu} / \mathrm{mL}$, and an aliquot of $0.2 \mathrm{~mL}$ was then added to microplate wells that were previously prepared to contain from $10^{0}$ to $10^{6} \mathrm{pfu} /$ well of the bacteriophage solutions. All tests were done in triplicate, and 2 controls were used: a sterile control containing only LB broth and a positive control that contained the $E$. coli isolate inoculated in LB broth without any bacteriophages. The $\mathrm{OD}_{600}$ was assessed on an hourly basis for a total of $10 \mathrm{~h}$. The miMOI was arbitrarily estimated as the minimum ratio of bacteriophage and bacteria that completely inhibited growth of the cells at the second hour of the beginning of the stationary phase of the positive control.

\section{Assessment of the Effect of a Single Dose $\left(\mathrm{MOI}=10^{2}\right)$ of Bacteriophage on the Growth Curve}

We expected that bacteriophages would be more effective in causing bacterial growth inhibition against their own host bacteria relative to other isolates with unknown susceptibility. Therefore, we decided to use an MOI that was greater than the greatest miMOI that completely inhibited bacterial growth of the cells at the second hour of the beginning of the stationary phase 
of the positive control, as previously established. The susceptibility of all 57 E. coli isolates to the 11 different bacteriophage solutions was evaluated. The E. coli isolates were grown in $\mathrm{LB}$ broth at $37^{\circ} \mathrm{C}$ for 6 to $8 \mathrm{~h}$ with shaking until an $\mathrm{OD}_{600}$ of $0.3\left(\sim 1 \times 10^{8} \mathrm{cfu} / \mathrm{mL}\right)$ was reached. The cultures were then diluted in LB broth to $10^{5} \mathrm{cfu} / \mathrm{mL}$, and an aliquot of $0.2 \mathrm{~mL}$ was then added to microplate wells that were previously prepared to contain a standard dose of $10^{6} \mathrm{pfu}$ of bacteriophage, which results in a ratio of $100 \mathrm{pfu}$ of bacteriophage for $1 \mathrm{cfu}$ of the $E$. coli isolate $\left(\mathrm{MOI}=10^{2}\right)$. All tests were done in triplicate, and 2 controls were used: a sterile control containing only LB broth and a positive control that contained the $E$. coli isolate in LB broth without any bacteriophages. The $\mathrm{OD}_{600}$ of the cultures was assessed on an hourly basis for a total of $12 \mathrm{~h}$, and an additional reading was done $24 \mathrm{~h}$ after inoculation.

\section{Bacteriophage Propagation, Isolation, and Concentration}

To assess the genetic diversity within and between the different bacteriophage preparations, bacteriophages were single-plaque isolated and propagated on their respective host strains; this technique was then repeated to warrant single bacteriophage isolation. Bacteriophages were propagated as follows: $0.2 \%$ inoculum of an overnight culture of the propagating host strain was added in $250 \mathrm{~mL}$ of $\mathrm{LB}$ broth and incubated at $37^{\circ} \mathrm{C}$ for $5 \mathrm{~h}$ with shaking. Approximately $1 \times 10^{9} \mathrm{pfu}$ of each isolated bacteriophage was added to the culture, and after incubation at $37^{\circ} \mathrm{C}$ for 20 min without shaking, the samples were incubated for a further 18 to $20 \mathrm{~h}$ at $37^{\circ} \mathrm{C}$ with vigorous shaking.

Concentrated phage preparations were obtained by $\mathrm{NaCl}$ polyethylene glycol 8000 precipitation of LB lysates in accordance with protocols described by Sambrook and Russell (2001). Solid $\mathrm{NaCl}$ at $1.0 M$ was added to each sample, and after stirring, the samples were maintained on ice for $1 \mathrm{~h}$. The samples were centrifuged at $11,000 \times g$ at $4^{\circ} \mathrm{C}$ for $10 \mathrm{~min}$ to remove debris, and the supernatants (LB lysates) were transferred to sterile flasks. Solid polyethylene glycol 8000 at a final concentration of $10 \%$ (wt/vol) was added to the lysates, and the samples were kept on ice for at least $1 \mathrm{~h}$ to allow the bacteriophage particles to precipitate. Precipitated bacteriophage particles were recovered by centrifugation at $11,000 \times g$ at $4^{\circ} \mathrm{C}$ for $10 \mathrm{~min}$ and resuspended in SM buffer. These large-scale high-titer lysate concentrated stocks were stored at $4^{\circ} \mathrm{C}$.

\section{Bacteriophage DNA Isolation and Restriction}

The extraction of bacteriophage DNA from large-scale high-titer lysate concentrated stocks was performed in small scale (Lockett, 1990). Contaminating bacterial nucleic acids were removed from concentrated phage solution by adding RNaseA (Sigma-Aldrich, St. Louis, $\mathrm{MO}$ ) and DNaseI (Sigma-Aldrich) to final concentrations of $20 \mu \mathrm{g} / \mathrm{mL}$ and $5 \mu \mathrm{g} / \mathrm{mL}$, respectively, followed by incubation for $30 \mathrm{~min}$ at $37^{\circ} \mathrm{C}$. After nuclease digestion, $0.25 \mathrm{~mL}$ of Tris-SDS (0.3 $M$ Tris-HCI, $100 \mathrm{mM}$ EDTA, $1.25 \%$ SDS, pH 9.0) was added, and the mixture was incubated at $65^{\circ} \mathrm{C}$ for $30 \mathrm{~min}$. To precipitate down the disrupted protein coat of the bacteriophages, $0.25 \mathrm{~mL}$ of ice-cold $3 M$ potassium acetate, $\mathrm{pH} 4.8$, was added, and the mixture was placed on ice for $5 \mathrm{~min}$. Insoluble material was removed by centrifugation at $15,000 \times g$ for $2 \mathrm{~min}$ at room temperature, and most of the supernatant was removed, taking care not to include any remaining insoluble flocculent material. Deoxyribonucleic acid was precipitated out by adding 0.7 volumes of isopropanol to the supernatant and, after a second 2 min at room temperature, recovered by centrifugation at $15,000 \times g$ for $1 \mathrm{~min}$. The DNA pellet obtained was dissolved in $0.3 \mathrm{~mL}$ of TE $(10 \mathrm{mM}$ Tris-HCI, $1 \mathrm{mM}$ EDTA, pH 8.0), $0.15 \mathrm{~mL}$ of $7.5 \mathrm{M}$ ammonium acetate was added to this solution, and DNA was reprecipitated with 2 volumes of cold ethanol. Another centrifugation at $15,000 \times g$ for $1 \mathrm{~min}$ at room temperature was carried out to spin down the DNA, which was then washed with $0.5 \mathrm{~mL}$ of $70 \%$ ethanol. The DNA pellet was dried at room temperature to remove traces of ethanol and then dissolved in TE. Purified bacteriophage DNA was subsequently digested with EcoRI (Promega, Madison, WI) and electrophoresed on $0.8 \%$ agarose as described by Sambrook and Russell (2001).

\section{Statistical Analysis}

To analyze the effect of a single dose of bacteriophage solutions on the growth curve of all 57 E. coli isolates, a general linear mixed model was fitted to the data using the MIXED procedure of SAS (SAS Inst. Inc., Cary, $\mathrm{NC}$ ). The outcome variable was the $\mathrm{OD}_{600}$ of the $\mathrm{LB}$ broth culture, which was modeled as a Gaussian (normally distributed data) variable. The assumption that the residuals were normally distributed was satisfied by visually evaluating the distribution plot of the studentized residuals. The independent variables offered to the model were treatment (11 different phage preparations and control) and time (from 1 until 12). The interaction of treatment and time was also included in the model. Our data were longitudinally collected and, therefore, had a series of repeated measures (total of 12) of optical density throughout the study period. This implies that data points were correlated within each E. coli isolate. To account appropriately for within correlation of the optical density, we modeled the error term by im- 


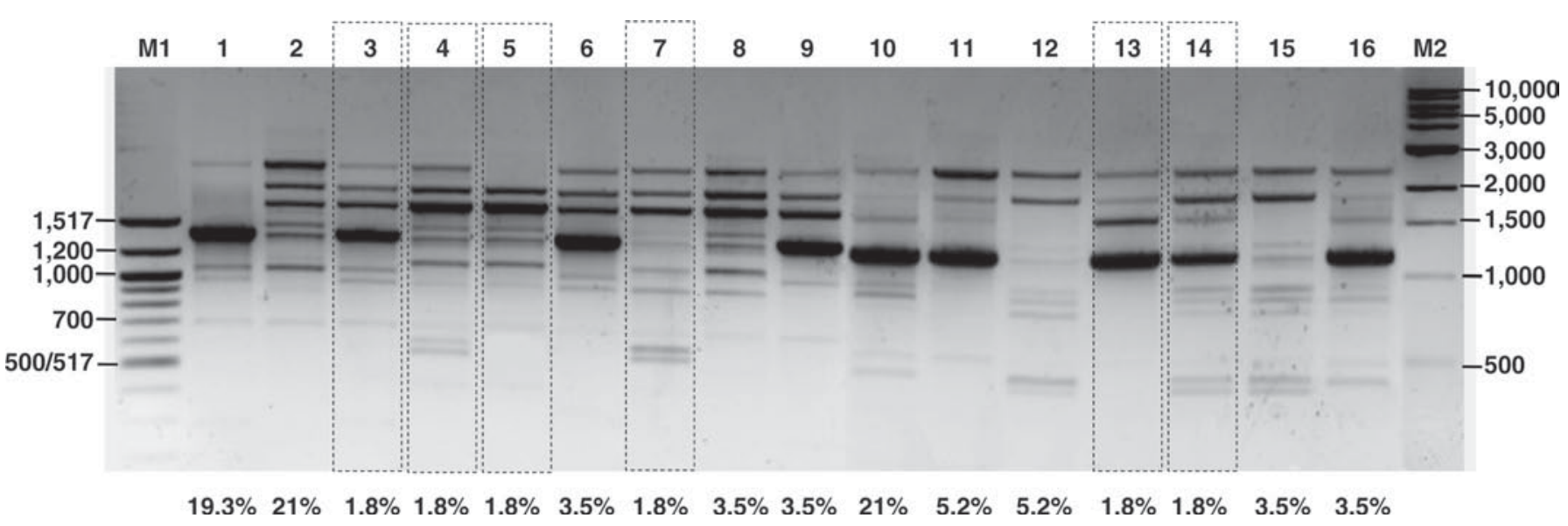

Figure 1. Randomly amplified polymorphic DNA-PCR (RAPD-PCR) of genomic DNA extracted from Escherichia coli isolated from uteri of postpartum dairy cows, showing genetic diversity of the isolates. DNA was electrophoresed on $0.8 \%$ agarose gel. Lane identification: (M1) 100 bp DNA ladder; (M2) 1.0 kb DNA ladder; (1-16) 16 different RAPD-PCR profiles observed between all 57 E. coli isolates. Enclosed lanes indicate unique profiles. Percentage below each lane indicates the frequency of the profile in the E. coli collection.

posing a first-order autoregressive covariance structure. Variables and interaction were considered significant at $P<0.05$.

\section{RESULTS}

\section{Bacterial Isolation and Characterization}

All isolates were confirmed to be $E$. coli both by cultural methods using chromogenic agar (Chromagar, DRG International) and by ribosomal DNA amplification. Evaluation of genotype of the 57 isolates by randomly amplified polymorphic DNA-PCR showed 16 different banding patterns for the isolates, of which 6 were observed to be unique profiles, indicating their relative diversity (Figure 1). Phylogenetic grouping based on triplex PCR showed that all isolates of E. coli belonged to phylogroup B1.

\section{miMOI}

To determine the miMOI, each host strain of $E$. coli was inoculated with 7 different doses of the respective bacteriophage preparation. The greatest MOI tested was $10^{2}$, which is equivalent to $100 \mathrm{pfu}$ of bacteriophage per $1 \mathrm{cfu}$ of the host E. coli. The least MOI tested was $10^{-4}$, which is equivalent to $1 \mathrm{pfu}$ of bacteriophage per $10,000 \mathrm{cfu}$ of the respective host $E$. coli. In general, bacterial growth was completely inhibited with extremely low MOI (Synnott et al., 2009), with the exception of phage preparations $4988-2$ and 2540-4, which had miMOI of $10^{1}$ and $10^{\circ}$, respectively (Figure 2). Furthermore, a dose-response effect was observed for all phage preparations; bacterial growth decreased as the MOI increased.

\section{Effect of a Single Dose $\left(\mathrm{MOI}=10^{2}\right)$ of Bacteriophage on the Growth Curve of All 57 E. coli Isolates}

Because we expected that the bacteriophages would be more effective in causing bacterial growth inhibition against their own host bacteria relative to other isolates with unknown susceptibility, we decided to use, as a single dose, MOI that was greater than the greatest miMOI that completely inhibited bacterial growth of the cells at the second hour of the beginning of the stationary phase of the positive control, which was MOI = $10^{2}$. When assessing the effect of a single-dose (MOI = $10^{2}$ ) inoculation of bacteriophage preparations on the growth curve of all $57 \mathrm{E}$. coli isolates, it was observed that all 11 bacteriophage preparations significantly $(P$ $<0.01)$ decreased the growth rate of the isolates when compared with the controls (Figure 3). However, it was also observed that some bacteriophage preparations were more effective than others. The average $\mathrm{OD}_{600}$ was least for the bacteriophage preparation 1230-10 (0.11, $95 \%$ confidence interval of 0.06 to 0.16 ) and greatest for the control $(0.37,95 \%$ confidence interval of 0.32 to 0.42) (Table 1). Furthermore, the number of isolates that were completely inhibited (final $\mathrm{OD}_{600}<0.10$ ) by single-dose bacteriophage inoculation differed between the different bacteriophage preparations $(P<0.01)$. Bacteriophage preparation 1230-10 had the greatest antimicrobial activity and completely inhibited the growth of $71.7 \%(\mathrm{n}=57)$ of all isolates. The combined action of bacteriophage preparations 1230-10, 6375-10, 2540-4, and 6547-2 had the broadest spectrum of action and completely inhibited the growth (final $\mathrm{OD}_{600}$ $\leq 0.1$ ) of $80 \%$ of the $E$. coli isolates and considerably inhibited the growth (final $\mathrm{OD}_{600} \leq 0.2$ ) of $90 \%$ of the E. coli isolates. 

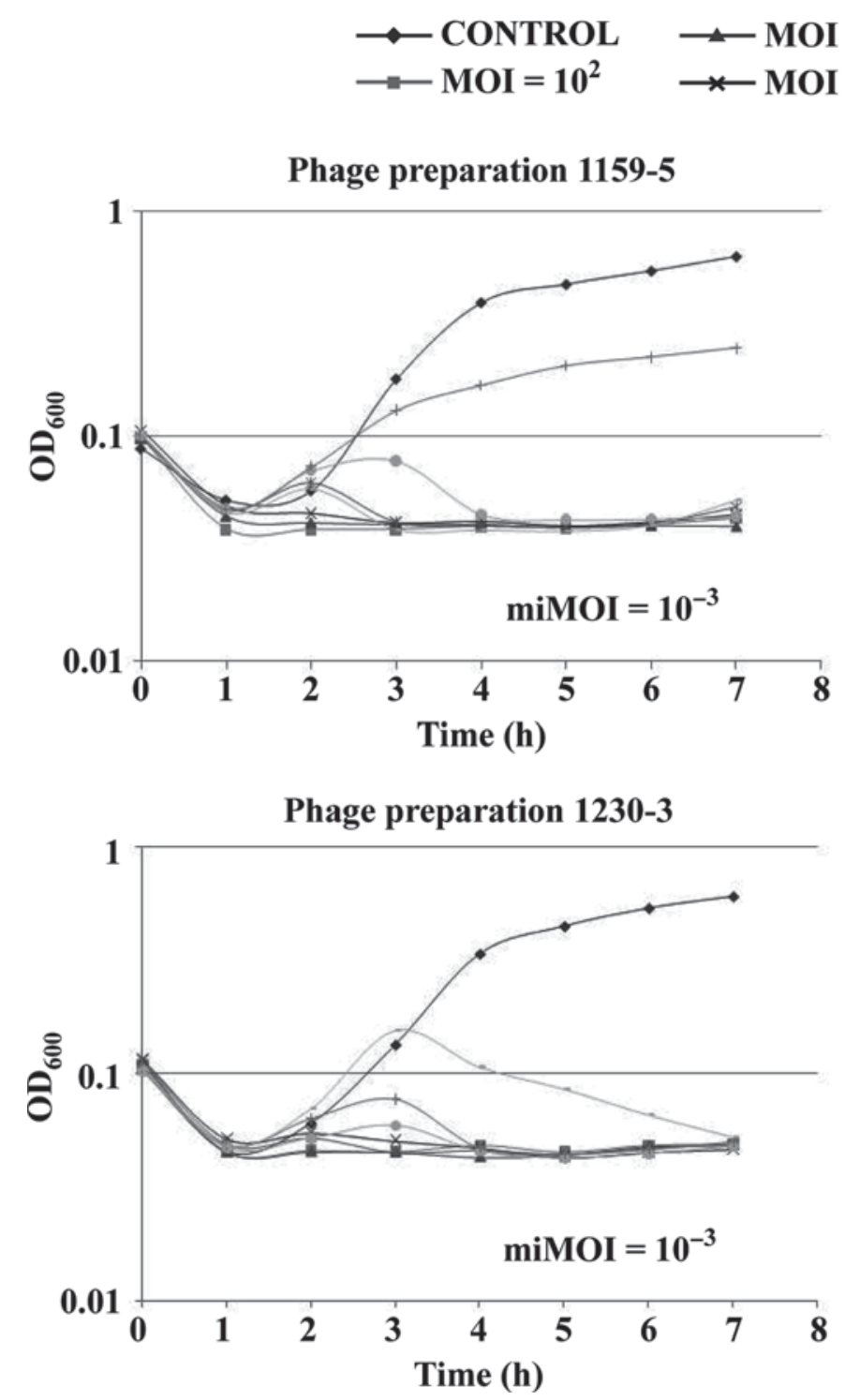

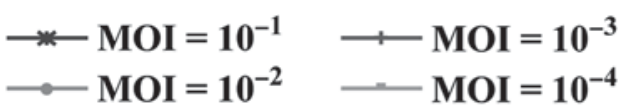

Phage preparation 1159-6
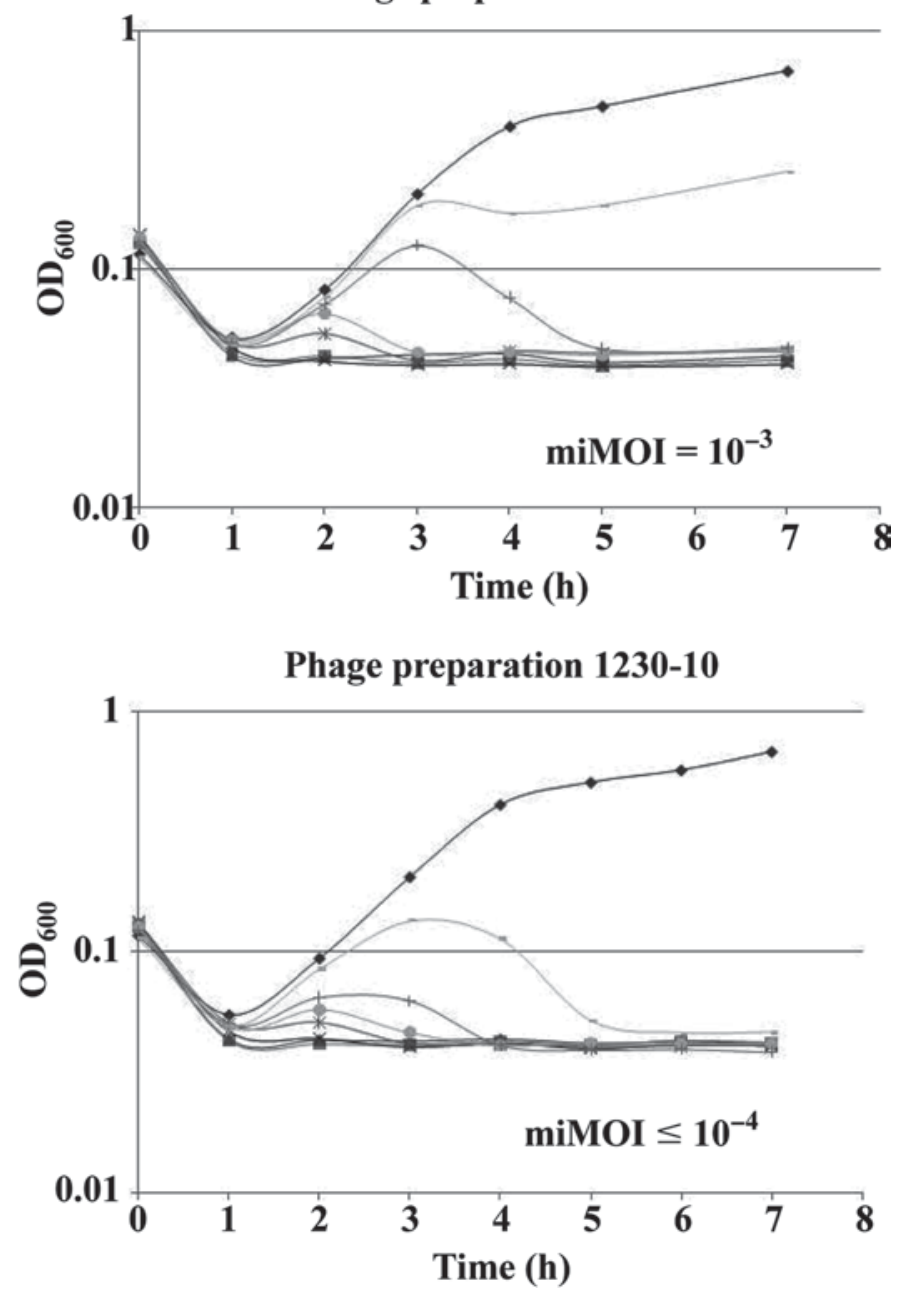

Figure 2. The effect of the inoculation of several different multiplicity of infection (MOI) on the growth curve of the host Escherichia coli bacteria. The minimum inhibitory MOI (miMOI) for each bacteriophage preparation is also reported. $\mathrm{OD}_{600}=$ optical density at $600 \mathrm{~nm}$.

\section{Bacteriophage DNA Isolation and Restriction}

To assess the genetic diversity within and between the bacteriophage preparations, DNA from the phage preparations $1230-10,6375-10,2540-4$, and 6547-2 was isolated, purified, digested with EcoRI (Promega, Madison, WI), and electrophoresed on $0.8 \%$ agarose gel. The restriction analysis demonstrated that all 4 phage preparations contained bacteriophages that were genetically distinct from each other based on the banding pattern of the fragments (Figure 4). In addition, it was observed that phage preparations $6547-2$ and 2540-4 contained a heterogeneous group of bacteriophages.

\section{DISCUSSION}

All isolates were confirmed to be E. coli both by cultural methods using chromogenic agar (Chromagar) and by ribosomal DNA amplification. Randomly amplified polymorphic DNA-PCR showed 16 different banding patterns for the isolates, and 6 profiles were observed to be unique, indicating relative diversity between the isolates. Phylogenetic grouping based on triplex PCR showed that all isolates of $E$. coli belonged to phylogroup B1, which generally includes both commensal nonpathogenic strains and some pathogenic strains. They typically lack the specialized virulence determi- 

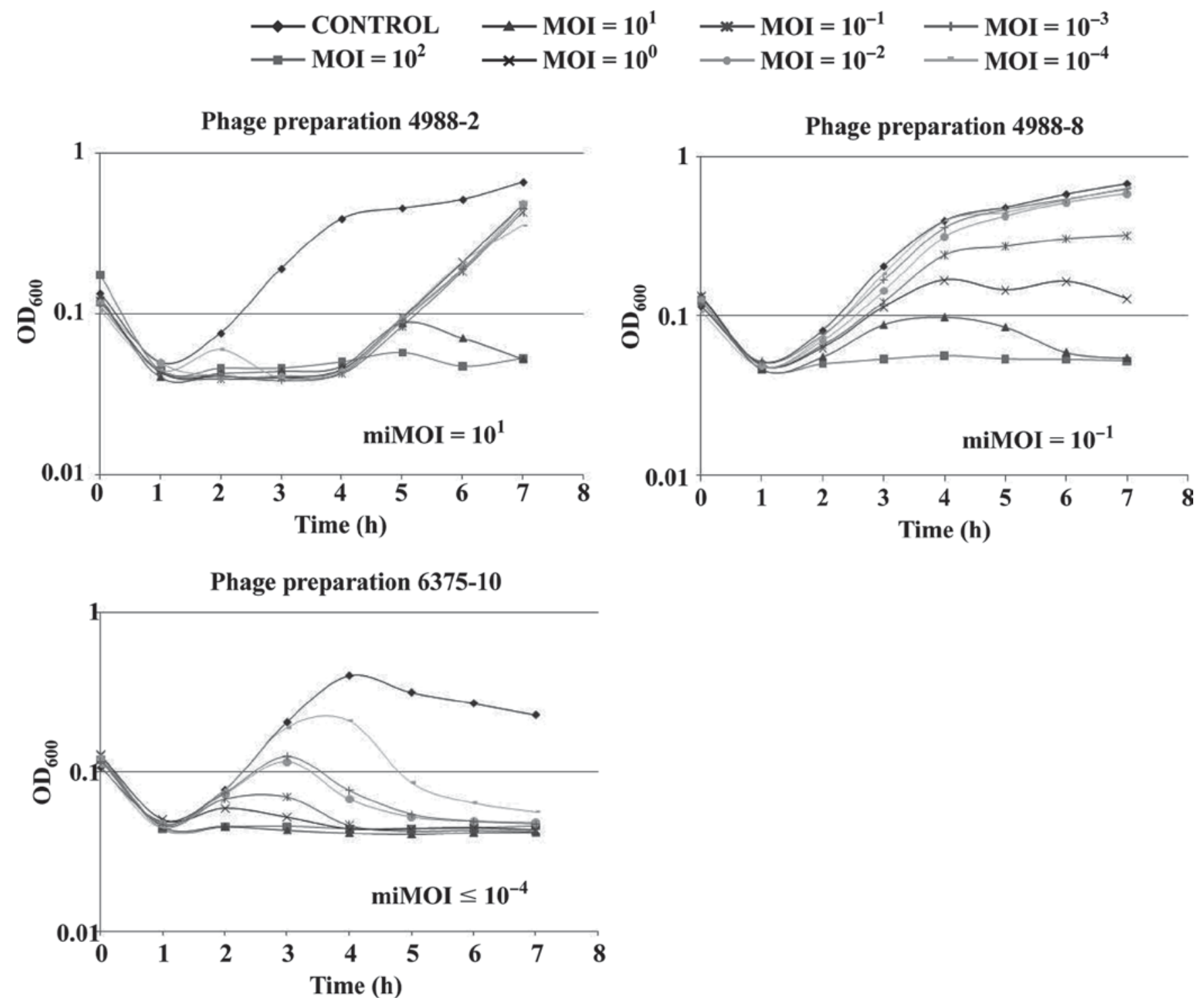

Figure 2 (Continued). The effect of the inoculation of several different multiplicity of infection (MOI) on the growth curve of the host Escherichia coli bacteria. The minimum inhibitory MOI (miMOI) for each bacteriophage preparation is also reported. $\mathrm{OD}_{600}=\mathrm{optical}_{\mathrm{a}}$ density at $600 \mathrm{~nm}$.

nants found in pathogenic strains that cause intestinal or extraintestinal diseases (Picard et al., 1999).

E. coli is a common cause of disease not only in food animals but also in humans. Several strains of E. coli are known to be virulent and to cause diseases such as gastroenteritis, urinary tract infection, peritonitis, mastitis, metritis, septicemia, and pneumonia (Clermont et al., 2000). However, strains of E. coli classified as nonpathogenic can also cause disease depending on the contamination load and the immunologic status of the animal (Schierack et al., 2006). Phylogenetic studies have shown that most $E$. coli strains can be grouped into 4 main phylogenetic groups (A, B1, B2, and D) in which most virulent extraintestinal strains typically belong to groups $\mathrm{B} 2$ or $\mathrm{D}$ and most commensal bacteria belong to group A (Herzer et al., 1990). In the current study, all E. coli were classified by the triplex PCR as belonging to the phylogenetic group B1, which represents potentially pathogenic bacteria (Herzer et al., 1990; Clermont et al., 2000). Although, the presence of a virulence factor in the genome of $E$. coli might partially explain the occurrence of metritis, it is important to emphasize that contamination load and immunologic status of the cow are equally important factors. Hammon et al. (2006) concluded that uterine disorders are associated with an impaired immune system of the 

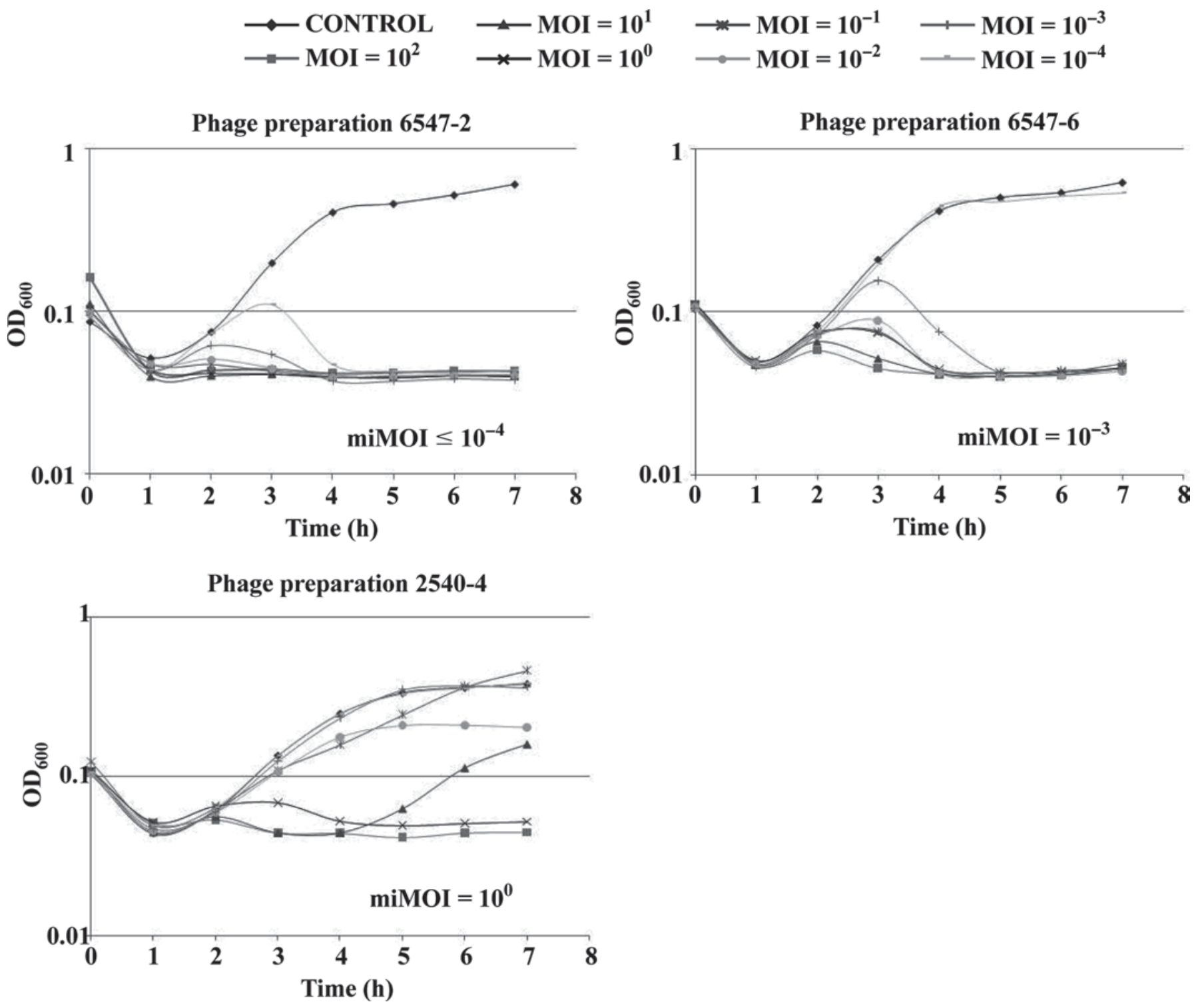

Figure 2 (Continued). The effect of the inoculation of several different multiplicity of infection (MOI) on the growth curve of the host Escherichia coli bacteria. The minimum inhibitory MOI (miMOI) for each bacteriophage preparation is also reported. $\mathrm{OD}_{600}=\mathrm{optical}_{\mathrm{l}}$ density at $600 \mathrm{~nm}$.

periparturient cow as a consequence of negative energy balance in the periparturient period. Silva et al. (2008) reported that the simple presence of virulence factors in the genome of $A$. pyogenes isolated from the uteri of dairy cows was not predictive of metritis. Schierack et al. (2006) reported that virulence factor gene profiles were similar for $E$. coli isolated from diarrheic piglets and normal piglets.

Bovine bacterial metritis might respond well to bacteriophage therapy because decreasing the bacterial load of $E$. coli is likely to decrease the severity of the disease (Sheldon et al., 2006), rapid clearance of bacteriophages from the circulatory system will not be a problem because intrauterine therapy is a viable option, there are an abundance of polyvalent environmental bacteriophages highly effective against $E$. coli (Brussow, 2005), and iatrogenic endotoxemia is less likely to happen with intrauterine versus intravenous administration of purified phage lysates. Gilbert et al. (1989) concluded that the intact endometrium prevented most of endotoxin uptake when intrauterine infusion of $E$. coli endotoxin was completed. Recent randomized clinical trials of bacteriophage therapy in mice and cattle have shown promising results. Biswas et al. (2002) successfully rescued mice that were inoculated with lethal doses of vancomycin-resistant E. faecium 
Table 1. Mean optical density at $600 \mathrm{~nm}\left(\mathrm{OD}_{600}\right)$ for the entire experiment period $(24 \mathrm{~h})$ by all bacteriophage solutions and the control ${ }^{1,2}$

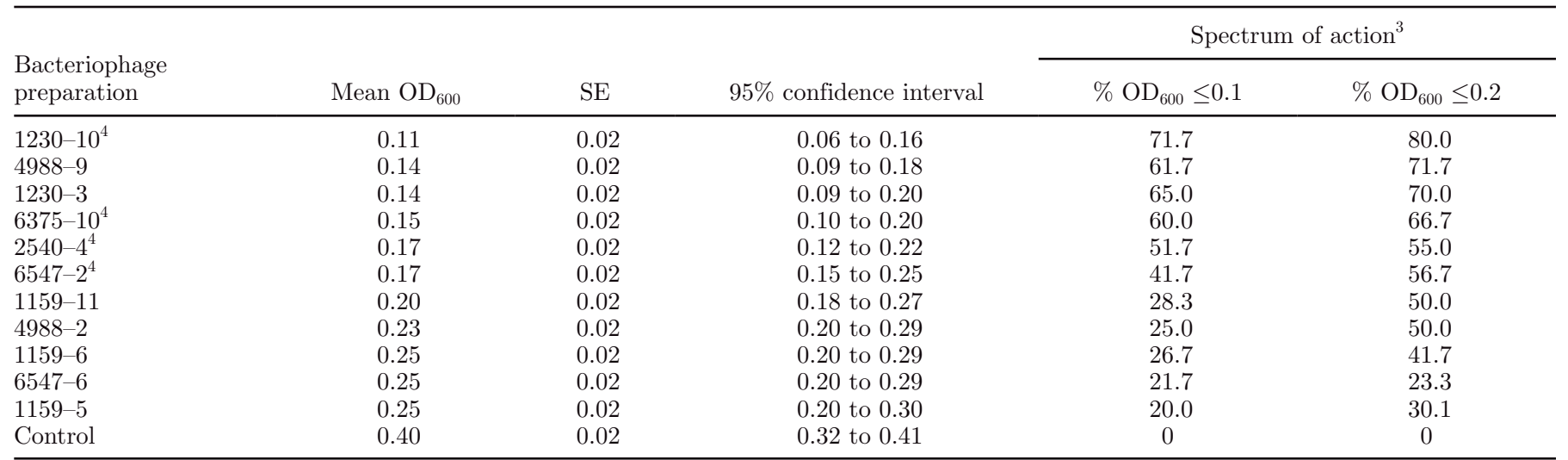

${ }^{1}$ A total of $57 \mathrm{E}$. coli isolates (isolated from the uteri of 5 postpartum cows) were treated with a dose of 100 pfu of bacteriophage per colony forming unit of bacteria (multiplicity of infection $=10^{2}$ ). All evaluated bacteriophage solutions were isolated from the manure ponds of 2 large commercial dairy farms.

${ }^{2}$ Data were analyzed using a general mixed linear model fitted with the MIXED procedure of SAS (SAS Inst. Inc., Cary, NC). The independent variables offered to the model were treatment (11 different phage preparations and control) and time (from 1 until 12). To account appropriately for within correlation of the optical density, the error term was modeled by imposing a first-order autoregressive covariance structure. Variables and interaction were considered significant at $P<0.05$.

${ }^{3} \% \mathrm{OD}_{600} \leq 0.1$ and $\% \mathrm{OD}_{600} \leq 0.2=$ percent of isolates that had an optical density equal to or less than 0.1 or 0.2 , respectively, at the end of the growth curve study.

${ }^{4}$ Combination of bacteriophage preparation that had the broadest spectrum of action.

with a single injection of a phage solution containing $3 \times 10^{8}$ pfu of a certain bacteriophage. Bacteriophage therapy was also reported successful when newly borne colostrum-deprived calves were inoculated with E. coli and treated with intramuscular inoculation of bacteriophages (Smith and Huggins, 1983). Although bacteria might develop resistance to phages, it is incomparably simpler to develop new phages than new antibiotics (Barrow et al., 1998). In nature, as bacteria evolve to develop resistance, relevant bacteriophages will evolve in concert (Inal, 2003), and only a few weeks are needed to obtain new phages for a newly emerging strain of resistant bacteria (Barrow et al., 1998; Inal, 2003). This is in favorable and sharp contrast to the process of discovering and developing a new chemical antibiotic.

In the current study, 11 bacteriophage preparations were isolated and characterized using standard techniques. All bacteriophage preparations successfully inhibited in vitro bacterial growth, and a strong dose response was observed for all preparations, indicating that greater MOI increased antimicrobial activity. We expected that bacteriophages would be more effective in causing bacterial growth inhibition against their own host bacteria relative to other isolates with unknown susceptibility. Therefore, we decided to use an MOI = $10^{2}$, which was greater than the greatest miMOI that completely inhibited bacterial growth in all treatments, to assess the effect of the bacteriophages on all E. coli isolates and to compose a cocktail with a wide range of hosts. Furthermore, it was observed that the use of dif- ferent bacterial isolates as bacteriophage hosts yielded genetically distinct bacteriophages. Brussow (2005) reviewed the literature that pertained to the use of bacteriophages as a therapeutic against E. coli diseases and reported that genetically distinct bacteriophages are isolated when different indicator cells from the same stool sample are used. In addition, we observed a genetic heterogeneity within some bacteriophage preparations, indicating that different bacteriophages were active against the same bacterial host. Nondigestion of Eco10 6547-2 suggests no sites for the enzymes EcoRI or the phage produce single-stranded DNA. Also, this bacteriophage could belong to the T-even like phages, which modify their DNA to protect it against the normal restriction system such that $99.9 \%$ of restriction enzymes will not cut it (Revel, 1967). Potential inhibitors in the DNA sample are possible but were not considered because clear restriction digestions were obtained from all other bacteriophages.

Human sewage has been considered to be one of the most diverse habitats for bacteriophages, and sewage samples are commonly used to search for novel bacteriophages (Lusiak-Szelachowska et al., 2006). In the current study, we used samples from manure systems of large commercial dairy farms. The manure lagoons of dairy farms hold thousands of tons of cattle waste, which is accumulated for up to $7 \mathrm{mo}$ at a time, allowing an incredible variety of microorganisms to thrive in that environment. Furthermore, environmental E. coli are known to be the cause of several diseases of dairy 


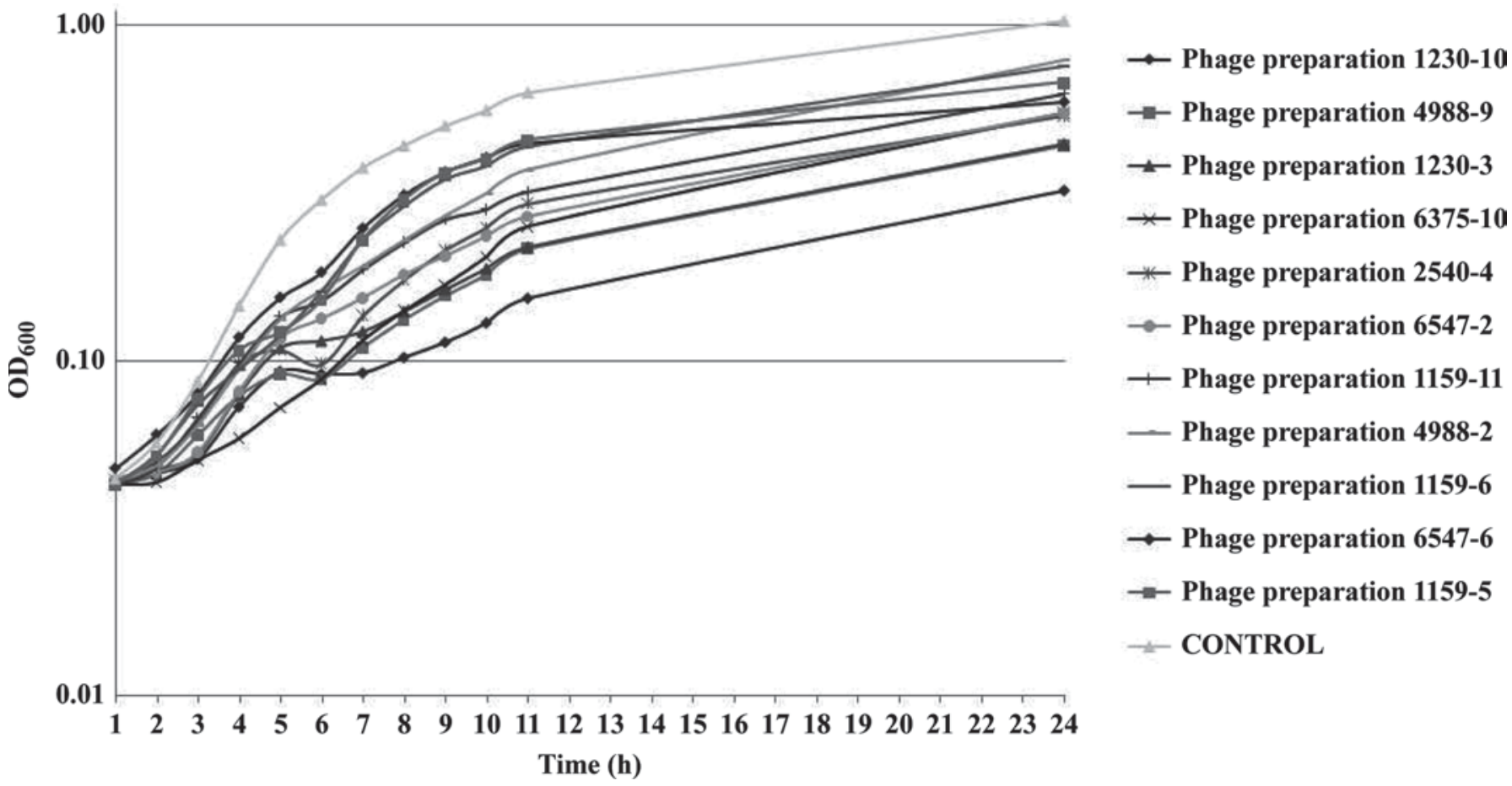

Figure 3. Mean growth curve [optical density at $600 \mathrm{~nm}\left(\mathrm{OD}_{600}\right)$ ] for all 57 Escherichia coli isolates, isolated from the uteri of postpartum cows, when inoculated with the 11 different bacteriophage solutions and in the absence of bacteriophage $($ control $)(P<0.01)$. All evaluated bacteriophage solutions were isolated from the manure ponds of 2 large commercial dairy farms.

cattle such as metritis (Sheldon, 2004), mastitis (Breen et al., 2009), and calf diarrhea (Schierack et al., 2006). In addition, it has been shown that host status is critical to the development of infections, regardless of the presence or absence of virulence factors or of chromosomal genetic markers status (Bingen et al., 1998; Schierack et al., 2006). Therefore, it is biologically plausible to target dairy manure systems when searching for potential therapeutic bacteriophages for dairy cattle.

One of the concerns with the use of phage therapy is the potential transfer of undesirable genes (virulence determinants and antibiotic resistance genes) from the bacteriophages to host bacteria and from a host bacterium to another (Chen and Novick, 2009). However, bacterial transduction is typically aided by lysogenic bacteriophages, as opposed to those that are lytic (potential antimicrobials). Nevertheless, genomic characterization of potential therapeutic bacteriophages would review the presence of undesirable genes, and if such genes were found, it would be prudent to not use those specific bacteriophages for therapy. Currently, there are no bacteriophage-based therapeutics approved by the United States FDA for the treatment of bacterial diseases of humans and animals. However, recently the FDA amended the food additive regulations to approve the use of a bacteriophage preparation on ready-to-eat meat and poultry (Lang, 2006). The use of naturally occurring bacteriophages in agriculture as a therapy for environmental diseases can be deemed harmless to humans and to the environment (Fischetti, 2001), especially if bacteriophages that were locally isolated were used because the magnitude of bacteriophage and host-bacteria interactions is exponentially greater in the environment than within a treated animal.

\section{CONCLUSIONS}

Several genetically diverse lytic bacteriophages, with strong antimicrobial activity against uterine $E$. coli isolates, were successfully isolated from the manure lagoon of commercial dairy farms. The individual bacteriophage preparations had excellent lytic activity against their own host E. coli isolates. When assessing the effect of a single-dose inoculation of bacteriophage preparations on the growth curve of $57 \mathrm{E}$. coli isolates, it was observed that all 11 bacteriophage preparations decreased the growth rate of the isolates when compared with the controls. Further in vitro and in vivo research is needed to assess the viability of bacteriophages as therapeutic agents for metritis. 
(A)

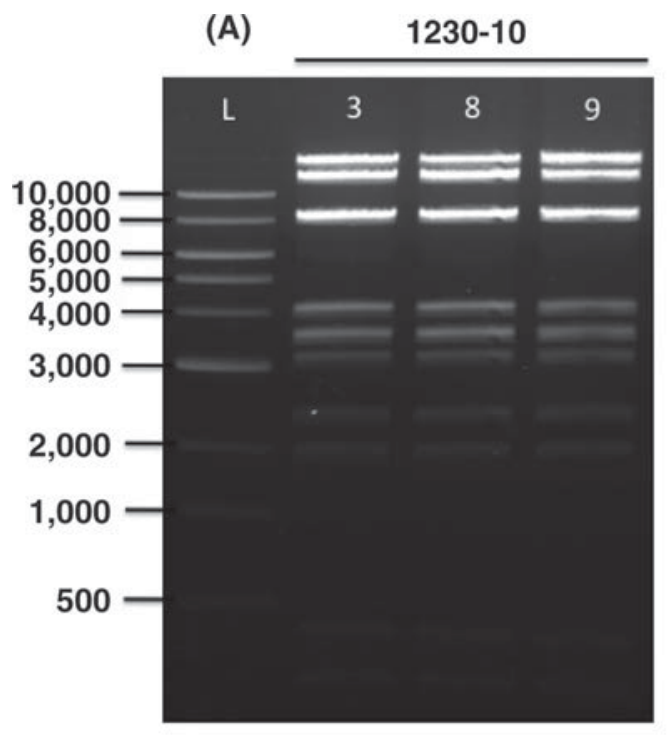

(C)

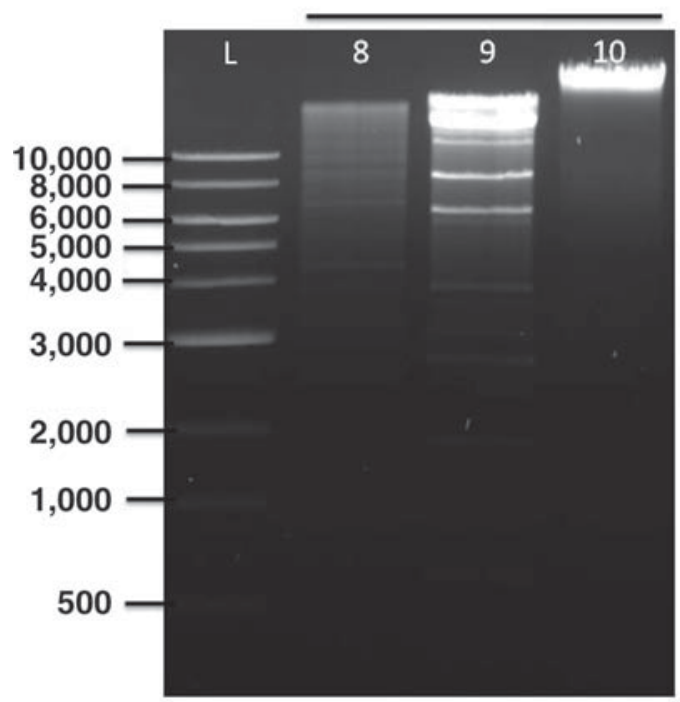

(B)

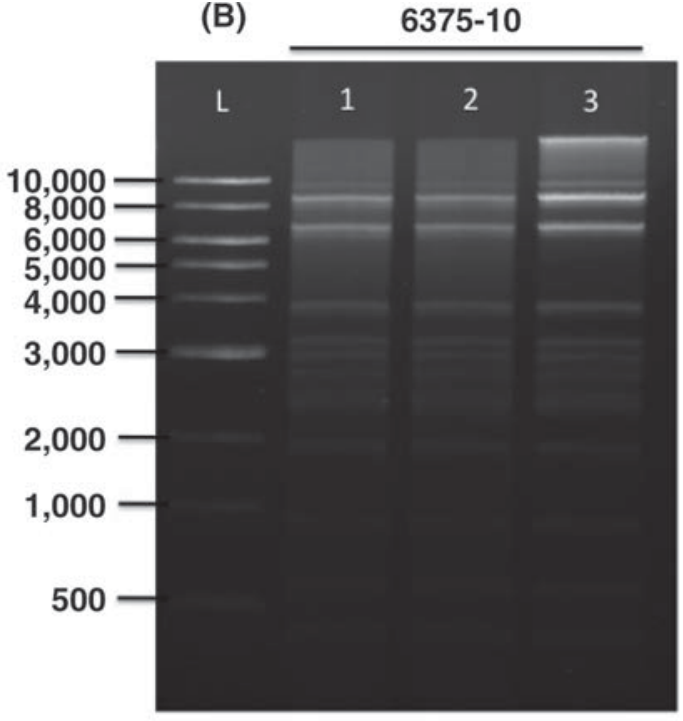

(D)

2540-4

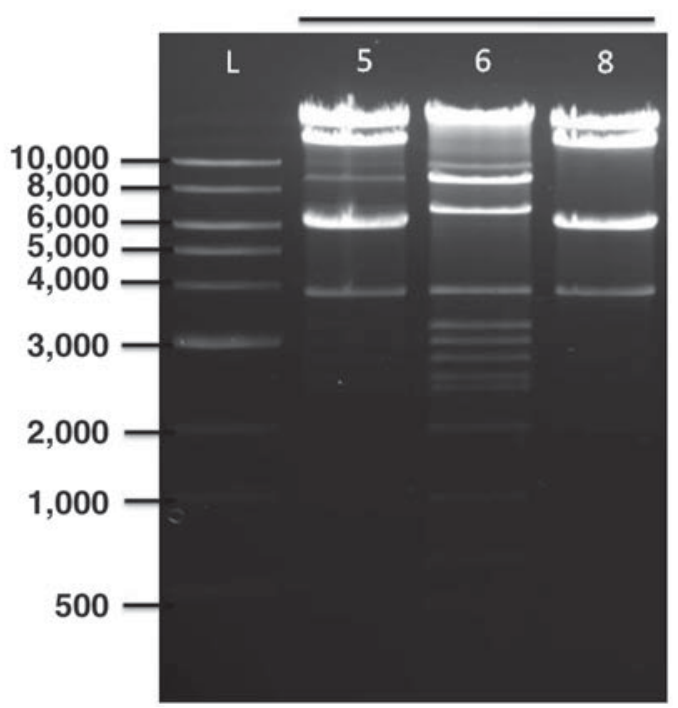

Figure 4. Restriction analysis of bacteriophage DNA from phage preparations 1230-10 [lanes 3, 8, and 9 (A)], 6375-10 [lanes 1, 2, and 3 (B)], 6547-2 [lanes 8, 9, and $10(\mathrm{C})$ ], and 2540-4 [lanes 5, 6, and 8 (D)]. DNA was digested with EcoRI (Promega, Madison, WI) and electrophoresed on $0.8 \%$ agarose gel. $\mathrm{L} 1=\mathrm{kb}$ DNA ladder.

\section{REFERENCES}

Barrow, P., M. Lovell, and A. Berchieri Jr.. 1998. Use of lytic bacteriophage for control of experimental Escherichia coli septicemia and meningitis in chickens and calves. Clin. Diagn. Lab. Immunol. 5:294-298.

Barrow, P. A., and J. S. Soothill. 1997. Bacteriophage therapy and prophylaxis: Rediscovery and renewed assessment of potential. Trends Microbiol. 5:268-271.

Bingen, E., B. Picard, N. Brahimi, S. Mathy, P. Desjardins, J. Elion, and E. Denamur. 1998. Phylogenetic analysis of Escherichia coli strains causing neonatal meningitis suggests horizontal gene transfer from a predominant pool of highly virulent B2 group strains. J. Infect. Dis. 177:642-650.

Biswas, B., S. Adhya, P. Washart, B. Paul, A. N. Trostel, B. Powell, R. Carlton, and C. R. Merril. 2002. Bacteriophage therapy rescues mice bacteremic from a clinical isolate of vancomycin-resistant Enterococcus faecium. Infect. Immun. 70:204-210.

Breen, J. E., M. J. Green, and A. J. Bradley. 2009. Quarter and cow risk factors associated with the occurrence of clinical mastitis in dairy cows in the United Kingdom. J. Dairy Sci. 92:2551-2561.

Brussow, H. 2005. Phage therapy: The Escherichia coli experience. Microbiology 151:2133-2140.

Chen, J., and R. P. Novick. 2009. Phage-mediated intergeneric transfer of toxin genes. Science 323:139-141.

Clermont, O., S. Bonacorsi, and E. Bingen. 2000. Rapid and simple determination of the Escherichia coli phylogenetic group. Appl. Environ. Microbiol. 66:4555-4558.

Clokie, M. R. J., and A. M. Kropinski. 2009. Bacteriophages: Methods and Protocols. Humana Press, Totowa, NJ.

d'Herelle, F. 1925. Essai de traitement de la peste bubonique par le bacteriophage. Presse Med. 33:1393-1394. 
Dohmen, M. J., K. Joop, A. Sturk, P. E. Bols, and J. A. Lohuis. 2000. Relationship between intra-uterine bacterial contamination, endotoxin levels and the development of endometritis in postpartum cows with dystocia or retained placenta. Theriogenology 54:10191032 .

Fischetti, V. A. 2001. Phage antibacterials make a comeback. Nat. Biotechnol. 19:734-735.

Foldi, J., M. Kulcsar, A. Pecsi, B. Huyghe, C. de Sa, J. A. Lohuis, P. Cox, and G. Huszenicza. 2006. Bacterial complications of postpartum uterine involution in cattle. Anim. Reprod. Sci. $96: 265-281$.

Gilbert, R. O., W. T. K. Bosu, and A. T. Peter. 1989. The effect of Escherichia coli endotoxin on luteal function in Holstein heifers. Theriogenology 33:645-651.

Hammon, D. S., I. M. Evjen, T. R. Dhiman, J. P. Goff, and J. L. Walters. 2006. Neutrophil function and energy status in Holstein cows with uterine health disorders. Vet. Immunol. Immunopathol. 113:21-29.

Herzer, P. J., S. Inouye, M. Inouye, and T. S. Whittam. 1990. Phylogenetic distribution of branched RNA-linked multicopy single-stranded DNA among natural isolates of Escherichia coli. J. Bacteriol. 172:6175-6181.

Inal, J. M. 2003. Phage therapy: A reappraisal of bacteriophages as antibiotics. Arch. Immunol. Ther. Exp. (Warsz.) 51:237-244.

Lang, L. H. 2006. FDA approves use of bacteriophages to be added to meat and poultry products. Gastroenterology 131:1370.

Lockett, T. J. 1990. A bacteriophage lambda DNA purification procedure suitable for the analysis of DNA from either large or multiple small lysates. Anal. Biochem. 185:230-234.

Lusiak-Szelachowska, M., B. Weber-Dabrowska, and A. Gorski. 2006. The presence of bacteriophages in human feces and their potential importance. Pol. Merkuriusz Lek. 21:381-383.

Malinen, E., A. Kassinen, T. Rinttila, and A. Palva. 2003. Comparison of real-time PCR with SYBR Green I or 5'-nuclease assays and dot-blot hybridization with rDNA-targeted oligonucleotide probes in quantification of selected faecal bacteria. Microbiology 149:269-277.

Merril, C. R., D. Scholl, and S. L. Adhya. 2003. The prospect for bacteriophage therapy in Western medicine. Nat. Rev. Drug Discov. 2:489-497.

Picard, B., J. S. Garcia, S. Gouriou, P. Duriez, N. Brahimi, E. Bingen, J. Elion, and E. Denamur. 1999. The link between phylogeny and virulence in Escherichia coli extraintestinal infection. Infect. Immun. 67:546-553.
Revel, H. R. 1967. Restriction of nonglucosylated T-even bacteriophage: Properties of permissive mutants of Escherichia coli B and K12. Virology 31:688-701.

Sambrook, J., and D. W. Russell. 2001. Molecular Cloning: A Laboratory Manual. 3rd ed. Cold Spring Harbor Laboratory Press, Cold Spring Harbor, NY.

Schierack, P., H. Steinruck, S. Kleta, and W. Vahjen. 2006. Virulence factor gene profiles of Escherichia coli isolates from clinically healthy pigs. Appl. Environ. Microbiol. 72:6680-6686.

Sheldon, I. M. 2004. The postpartum uterus. Vet. Clin. North Am. Food Anim. Pract. 20:569-591.

Sheldon, I. M., M. Bushnell, J. Montgomery, and A. N. Rycroft. 2004. Minimum inhibitory concentrations of some antimicrobial drugs against bacteria causing uterine infections in cattle. Vet. Rec. $155: 383-387$.

Sheldon, I. M., G. S. Lewis, S. LeBlanc, and R. O. Gilbert. 2006 Defining postpartum uterine disease in cattle. Theriogenology 65:1516-1530.

Silva, E., M. Gaivao, S. Leitao, B. H. Jost, C. Carneiro, C. L. Vilela, L. Lopes da Costa, and L. Mateus. 2008. Genomic characterization of Arcanobacterium pyogenes isolates recovered from the uterus of dairy cows with normal puerperium or clinical metritis. Vet. Microbiol. 132:111-118.

Smith, H. W., and M. B. Huggins. 1983. Effectiveness of phages in treating experimental Escherichia coli diarrhea in calves, piglets and lambs. J. Gen. Microbiol. 129:2659-2675.

Summers, W. C. 2001. Bacteriophage therapy. Annu. Rev. Microbiol. $55: 437-451$.

Synnott, A. J., Y. Kuang, M. Kurimoto, K. Yamamichi, H. Iwano, and Y. Tanji. 2009. Isolation from sewage influent and characterization of novel Staphylococcus aureus bacteriophages with wide host range and potent lytic capability. Appl. Environ. Microbiol. 75:44834490

Wang, G., T. S. Whittam, C. M. Berg, and D. E. Berg. 1993. RAPD (arbitrary primer) PCR is more sensitive than multilocus enzyme electrophoresis for distinguishing related bacterial strains. Nucleic Acids Res. 21:5930-5933.

Zerbe, H., C. Ossadnik, W. Leibold, and H. J. Schuberth. 2001 Influence of Escherichia coli and Arcanobacterium pyogenes isolated from bovine puerperal uteri on phenotypic and functional properties of neutrophils. Vet. Microbiol. 79:351-365. 